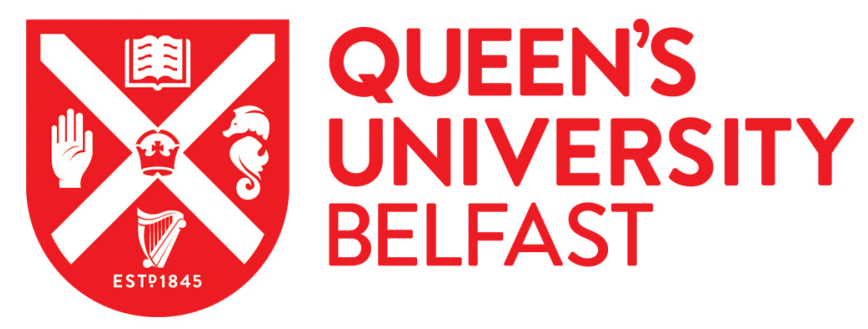

\title{
"There are thousands who will claim to have been 'out' during Easter Week.": Recognising military service in the 1916 Easter Rising
}

Coleman, M. (2018). "There are thousands who will claim to have been 'out' during Easter Week.": Recognising military service in the 1916 Easter Rising. Irish Studies Review, 26(4).

https://doi.org/10.1080/09670882.2018.1523355

Published in:

Irish Studies Review

Document Version:

Peer reviewed version

Queen's University Belfast - Research Portal:

Link to publication record in Queen's University Belfast Research Portal

Publisher rights

(c) 2018 Informa UK Limited, trading as Taylor \& Francis Group. This work is made available online in accordance with the publisher's policies. Please refer to any applicable terms of use of the publisher.

\section{General rights}

Copyright for the publications made accessible via the Queen's University Belfast Research Portal is retained by the author(s) and / or other copyright owners and it is a condition of accessing these publications that users recognise and abide by the legal requirements associated with these rights.

Take down policy

The Research Portal is Queen's institutional repository that provides access to Queen's research output. Every effort has been made to ensure that content in the Research Portal does not infringe any person's rights, or applicable UK laws. If you discover content in the Research Portal that you believe breaches copyright or violates any law, please contact openaccess@qub.ac.uk. 
"There are thousands who will claim to have been 'out' during Easter Week.": Recognising military service in the 1916 Easter Rising'

Dr Marie Coleman

School of History, Anthropology, Philosophy and Politics, Queen's University Belfast, Belfast BT7 1PA, Northern Ireland.

m.coleman@qub.ac.uk

(028) 90973255

ORCID: 0000-0001-9021-8932 


\section{Introduction}

"I was at home on my holidays in 1916 for the reason that the people who made the rebellion did not think me sufficiently important to tell me that there was going to be a rebellion."1

This was the defence offered by Michael Tierney, a Cumann na nGaedheal TD, in Dáil Éireann in 1930, in response to goading from the opposition Fianna Fáil TD, Dr James Ryan (a veteran of the General Post Office garrison during the Easter Rising), that Tierney was a shirker during the Rising and "had remained in his digs in Leeson Street". ${ }^{2}$ The exchange encapsulates how, for many of the first generation of political leaders in independent Ireland, having played a role in the Easter Rising was an important badge of honour. As Charles Townshend has noted "Participation in the rebellion, or at least the ability to suggest it, became a key part of every nationalist politician's resumé."3

In the one hundred years since the Rising the numbers who claimed to have participated in it, and especially to have been present at the epicentre in the General Post Office (GPO) on Sackville (now O’Connell) Street, have gained mythical status. By 1924 the number of people alleged to have been in the GPO was "already the butt of jokes", such as a cartoon in the satirical revue, Dublin Opinion, which mocked the GPO as having "held 30,000 patriots in $1916 " .4$ Over one hundred years on, the question still remains of how many people were actually "out" in 1916 ?

Recently released figures from the Irish Military Archives showing the number of people recognised by the state as having active service during the Rising for pension and medal purposes now provides an opportunity to consider how many male and female volunteers took an active part in the 1916 Rising. The release of the Military Service Pensions 
Collection (MSPC) online was a central plank of the Irish government's extensive programme for commemorating the centenary of the Easter Rising. ${ }^{5}$ The construction of a new purposebuilt home for the Military Archives accounted for $€ 5.4$ million of the $€ 49$ million spent on the 1916 commemorations. ${ }^{6}$ It will survive as a significant legacy of the Irish state's official commemorations of the Decade of Centenaries.

The collection, which contains 300,000 files relating to service, disability, and dependants' pensions awarded to veterans of the Irish revolution (1916-23) and their families, is extremely valuable for increasing our knowledge of the Rising. The individual applications provide significantly greater detail on activities during Easter week, especially outside Dublin. Even those who were not successful in receiving recognition for their activities during the Rising have left valuable narratives of their actions. The MSPC is a much more detailed source of testimonies from women than the Bureau of Military History (BMH); as of January 2018 there are 848 pension files and 4,607 medal files relating to women in the MSPC, compared to 153 written and oral statements from women in the BMH. The fate of widows, children, and other dependants of rebels who died can now be traced through the pensions awarded to them. ${ }^{7}$ The physical and psychological impact on rebels whose health broke down as a result of their activities emerge from the files relating to disability pensions. ${ }^{8}$ Although a definitive figure for the number of rebels who participated in the Rising can never be produced, these archives offer a valuable opportunity to analyse how the decision that someone had done their bit in 1916 was taken.

The pension files provide specific details on numerous engagements undertaken by the rebels. However, this cannot be taken at face value without an understanding of the context in which the information was provided, often in response to specific questions posed by the assessors in oral testimony. Furthermore, this article will show how interpretations of 
assessment criteria varied considerably over the thirty-four year life span of the pensions. To appreciate fully the significance of the detail contained in the MSPC files it is essential to be aware of the different attitudes of specific assessors at any given time.

\section{Who was "out" in 1916?}

The MSPC has listed 2,594 veterans who were recognised as having service in 1916 by the award of either a military service pension, a 1916 service medal, or a pension or allowance given to the family of a rebel who died during the Rising. ${ }^{9}$ The release was mis-reported in sections of the Irish press as being the definitive "number of people who took part in the 1916 Easter Rising”, whereas it excludes those who did not apply for, or were refused, pensions or service medals, and some who had died between 1916 and the issue of pensions and medals, including Cathal Brugha and Constance Markievicz. ${ }^{10}$

Prior to the release of this list various other efforts had been made to assemble a numerical estimate of those who had taken part in the Rising. The most reliable contemporary account appears to be the Irish Times' Sinn Fein Rebellion Handbook, published in 1917, which listed 3,149 men and 77 women who had been arrested between April and July $1916 .{ }^{11}$ The 1916 roll of honour, produced by veterans for the National Museum of Ireland on the twentieth anniversary in 1936, listed 1,655 as taking part in the activities of the various Dublin city garrisons. ${ }^{12}$ There were "many omissions" from the roll, including Richard Mulcahy and James Connolly's three children - Roddy, Ina and Nora. Women were particularly overlooked because many of them were "in and out" of the GPO throughout the week; in total 157 women signed the roll of honour. ${ }^{13}$ Jimmy Wren's recent research has suggested that 572 is a "credible total number of insurgents that served at various times 
throughout Easter Week in the GPO area". ${ }^{14}$ Approximately 400 more were involved throughout the week in the Four Courts garrison and a further 28 in the Mendicity Institute. ${ }^{15}$ Joseph E. A. Connell's estimate for the total number who took part throughout Dublin is somewhere between 1,950 and $2,170 .{ }^{16}$ Contemporaries advised the pension assessors that the nominal strength of the Dublin Volunteers was around 3,000, about 900-1,000 of whom might have taken an active part. ${ }^{17}$

The roll of honour was confined to the Dublin garrisons and Ashbourne in neighbouring County Meath, excluding veterans from areas outside the capital, especially Enniscorthy in County Wexford and Athenry in County Galway. Historians have had to rely largely on personal accounts of participants to estimate the numbers who mobilised or took an active part in the areas outside Dublin that saw the most activity. Approximately 500-600 Volunteers, and some apparent hangers-on, were said to have joined forces with Liam Mellows in Athenry and a similar figure to have occupied buildings in the town of Enniscorthy for the latter half of Easter week. ${ }^{18}$ A further 131 Louth Volunteers have been identified as mobilising throughout the week. ${ }^{19}$

The principal form of recognising military service in the Rising was the award of a military service pension. These pensions were introduced by the Cumann na nGaedheal government in 1924 and awarded to veterans who could prove they had given service to the required level during the period from the Rising to the end of the Civil War in 1923. Eligibility was initially restricted to pro-Treaty supporters who had fought for the National Army against the Irish Republican Army (IRA) in the latter conflict, resulting in a very low number of awards during the first ten years in which the scheme operated. In 1934, under Fianna Fáil, anti-Treaty republicans, Cumann na mBan woman, Civil War neutrals, and those who undertook a civilian rather than a military role in the latter conflict all became eligible. ${ }^{20}$ 
During the lifetime of the pensions' process, between 1924 and 1958, approximately 18,000 pensions were awarded out of a total of over 80,000 applications. An early legislative failure to define what constituted the "active service" upon which pensions were to be awarded, dogged the process throughout this period, and an applicant's success or otherwise was often down to the subjective interpretation of the pension assessors. Initially, starting in 1924, pensions were assessed by a three-person Board of Assessors, chaired by a Referee. In 1934 these were replaced by a Referee and four-person advisory committee. ${ }^{21}$ The Referee was a judge, of the district or circuit courts, while his advisors were a combination of civil servants and senior IRA figures from the revolutionary period. For much of the period between 1934 and 1939, when the bulk of applications were assessed, the two IRA veterans on the Advisory Committee were John McCoy, a close associate of the Fianna Fáil Minister for Defence, Frank Aiken, and Seamus Robinson, a former Fianna Fáil senator who had been a prominent Volunteer leader in Tipperary during the revolution. Robinson was a recognised veteran of the Rising, having fought in the GPO garrison, while Eamon Duggan, a member of the Board of Assessors during the 1920s, had been in the Four Courts garrison.

Of the 2,594 veterans with recognised military service for 1916, the vast majority 2,281 (88 per cent) - had such service recognised with the award of military service pensions [Table 1]. Only 463 of these were awarded under the restrictive 1924 legislation which limited awards to pro-Treaty veterans with Civil War service. All of these recognised military service pensioners were entitled to receive the 1916 medal, introduced in 1941 for the twenty-fifth anniversary, as were those who had not applied for a pension but would have met pensionable standard had they done so, such as Eamon de Valera. 127, accounting for five per cent, (112 men and 15 women) received medals only; some of these, including Harry Boland, had died during the revolution and their families sought the medals as a form of 
posthumous recognition. ${ }^{22}$ A further 171 (6.5 per cent) men who died during the Rising or between the Rising and the advent of pensions were credited with 1916 service through dependants' pensions awarded to their families. These included the widows of the signatories of the Proclamation and Roger Casement's sister. ${ }^{23}$ The remaining 15 are from an internal list compiled by the Department of Defence. ${ }^{24}$

One pension awarded in this category was given to Michael Collins's sister, Mrs Mary Collins Powell. Following the death of her husband, Patrick Powell, in 1919, she was left with eight children under the age of 18 , and subsequently undertook the care of three of another brother's children, aged between three and five, after their home was destroyed by the Crown forces during the War of Independence. ${ }^{25}$ From the time of Patrick Powell's death, Michael Collins had helped her out financially and materially "with gifts in cash and in kind" and had "promised her he would afford her considerable help in maintaining herself and her children." The government agreed that she had suffered a loss following his death, "Having regard to the eminent position held by General Collins - a single man - at the time of his death in 1922 and to the position of authority and comparative affluence which would have been open to him for at least ten years afterwards", and awarded her an annual allowance of $£ 125$.

What is unusual about her application is that it was not made until 1953, over thirty years after her brother's death. Collins-Powell admitted that for "idealistic reasons' she had turned down an offer from W. T. Cosgrave in 1922 to enact a civil list pension for her, similar to that passed to provide for Arthur Griffith's widow, Maud, and her two children. Collins-Powell argued that her 1953 application should take account of her circumstances at the time of the death of Michael Collins and not her actual circumstances at the time of her application. ${ }^{26}$ Her motivation for applying at this late stage appears to have been the need to 
augment her small local authority pension, an indication of the monetary significance of pensions for dependants many years after the revolution. ${ }^{27}$ Michael Collins's inclusion on the list of recognised 1916 veterans resulted from a posthumous application for his 1916 medal by his brother, Seán Collins, indicating how official recognition often depended on the subsequent actions of a deceased veteran's family. ${ }^{28}$

\section{Defining "active service" in the Easter Rising}

At an early stage in the pension process it was decided that service during the Rising would be considered separately from "active service" during the subsequent period to 1921 or in the Civil War, given the very different nature of the Rising from the subsequent guerrilla campaigns. From the outset, Gearóid O'Sullivan, a former revolutionary and army officer who served as secretary to the Board of Assessors, warned that "there are thousands who will claim to have been 'out' during Easter Week." The Board decided to limit 1916 service to Dublin city and county and counties Wexford, Galway, Meath and Louth, and to exclude Volunteers who mobilised elsewhere but were subsequently ordered to "stand to", "disperse" or "disperse and await further orders." 29 This policy of recognising service in these four theatres was continued by the Referee and the Advisory Committee which replaced the Board of Assessors. ${ }^{30}$ This would later cause considerable resentment from many who had mobilised outside Dublin for action that never materialised.

This was especially the case with northern Volunteers whose mobilisation in Belfast and Dungannon was not recognised as pensionable service for Easter week. As such, prominent northern republicans like Denis McCullough, chairman of the supreme council of the IRB at the time of the Rising, are not in the MSPC list of those with recognised 1916 
service. Dr Patrick McCartan was refused a pension, presumably because his 1916 service was outside the recognised theatres and his subsequent service was political rather than military. ${ }^{31}$ Sean Cusack, a Belfast Volunteer who mobilised and travelled to Tyrone on Holy Saturday, received a pension on the basis of subsequent service, but not for $1916 .{ }^{32}$ John McElvogue also mobilised in Tyrone and was arrested after the Rising and imprisoned in Wandsworth, but is not considered to have recognised 1916 service. ${ }^{33}$ James Hannan's claim for a pension based on transferring weapons between Belfast and Tyrone during the Ulster mobilisation was similarly unsuccessful. ${ }^{34}$

Those awarded pensions for service in 1916 were recognised on the basis of these geographic guidelines. Of the 2,281 military service pensioners of the Rising, 1,544 (68 per cent) were primarily involved in actions in Dublin, although some also saw service at Ashbourne in County Meath [Table 2]. The next highest figure of recognised pension veterans, 401 (17 per cent), were involved in operations in Galway, while 268 (12 per cent) and 39 ( 2 per cent) were from the Wexford and Meath/Louth regions respectively. The remaining 1 per cent of pensions was awarded to a very small number of veterans (29) recognised for actions outside the four main theatres. ${ }^{35}$

The nature and extent of the rebel leaders' plans for a Rising outside of Dublin remains contested, with some veterans subsequently claiming it was an integral part of the strategy and others that it was an afterthought. Historians largely agree that the organisers "primarily focused their efforts on Dublin" because of its significance as the capital and the strength of the Volunteers there. To the extent that there was a specific plan for the role of Volunteers from the neighbouring counties of Louth and Meath it appears to have been to encircle the city and county to prevent British armed reinforcements accessing Dublin from the provinces. ${ }^{36}$ On Easter Monday some Louth Volunteers en route to Dublin were involved 
in an altercation at Castlebellingham that led to the death of a Royal Irish Constabulary (RIC) constable, Charles McGee. ${ }^{37}$

Plans for a Rising in Galway that would notionally be joined by rebels from Ulster, were thrown into disarray by apparent internal divisions, MacNeill's countermanding order of Easter Sunday, and the failure of Casement's arms shipment which was intended to supply the westerners with the arms required to rise. The arrival of Liam Mellows on Easter Monday brought a much needed level of organisation and coherence. Mellows proved himself one of the more effective rebel leaders concentrating on a limited uprising in east county Galway where the strongest force of Volunteers had mobilised. The principal actions in Galway involved symbolic but unsuccessful attacks on RIC stations at Oranmore, Clarenbridge and Gort on Easter Tuesday and a shoot-out with police at the crossroads in Carnmore that led to the death of Constable Patrick Whelan. ${ }^{38}$ By Wednesday the bulk of the Galway Volunteers (estimated at 500) gathered at a government agricultural centre in Athenry from where they dispersed to more suitably defensive outposts at Moyode Castle and Lime Park House. The Galway Volunteers saw no further action before disbanding on Easter Saturday, by which time a significant number had already returned to their homes. ${ }^{39}$

The town of Enniscorthy in Wexford was held by the rebels from Thursday until the Monday following Pearse's surrender. The reason for this unusual reversal in the trend of regions outside Dublin, where activity lessened rather than increasing as the week wore on, appears to have been the arrival on Wednesday evening of Peter Paul Galligan, who had cycled all the way from Dublin with specific instructions to prevent railway travel from the south to Dublin. From their base in the Athenaeum social club the rebels held the town with little resistance from the out-numbered local RIC. No policemen were killed during the occupation. $^{40}$ 
It is no surprise that the greatest proportion of pensioners were from Dublin. Nevertheless, the evidence suggests that the Dublin veterans had an easier time of convincing the assessors of the merits of their service than had the pension applicants from Galway, Wexford, Louth and Meath. Within the city it was not essential to have taken part in the actual fighting and those who "were members of a garrison of a fortified military post in an area in which such conflict did occur" but "did not take part in the conflict" were credited with pensionable service, while in Dublin county Volunteers who mobilised on Easter Sunday and remained in service throughout the week "taking part in all operations, including the fight at Ashbourne, and who were present at the surrender" were also successful with their pension applications. These generous criteria left only a few hundred, "who rendered meritorious service such as carrying messages, procuring provisions, quelling rioting, \&c, who did not qualify for pensions" in Dublin on the basis of 1916 activity. ${ }^{41}$

The favourable treatment shown to Dublin rebels is exemplified by the pension awarded to Ernie O’Malley in 1935. O’Malley was not involved in politics prior to 1916, when he was a medical student in Dublin, and the Rising is generally seen as the key point in his subsequent politicisation. As his biographer, Richard English, notes, "His own words testify with a characteristic sense of drama to a Damascus Road experience: 'Then came like a thunderclap the 1916 Rising,." 42 In 1935 he was credited with having three days of active service during Easter week as a member of the Irish Volunteers. ${ }^{43}$ In his memoir, On Another Man's Wound, written contemporaneously with his pension application, O'Malley asserted that he did not join the Volunteers until Christmas $1916 .{ }^{44}$ Nor was there any mention of serious participation in the Rising in a letter which he wrote in prison to the widow of Erskine Childers in late 1923 explaining the effect 1916 had on his subsequent politicisation. ${ }^{45}$ 
In all subsequent versions of his memoir he refers to meeting up with an old school friend and both of them taking part in sniping activities at various locations around Dublin for the latter half of Easter week. ${ }^{46}$ It is unclear how it was decided to award him Easter week service as the file containing his application and transcripts of evidence to the Advisory Committee is not in the MSPC. Some of his correspondence with the pensions' boards exists in his papers in New York University, which shows that in his application for a military service pension in 1934 he stated that:

In Easter Week 1916 I fought for 3 nights: Wednesday, Thursday and Friday with another boy, now a captain in the British navy. We harried outposts from Cross Guns Bridge to Charlemont Bridge crawling up close to them, using a rifle. I was not attached to any unit then and discovered my real feelings only during that week's fighting. I do not know if my brothers, Paddy and Cecil, can verify my absence; my people did not know I fought. I cannot give the naval officer's name without his consent.

He went on to state that he did not join the join the Volunteers "until August or so of $1916 " .47$

Not only do the pension assessors appear to have taken him at his word for the three days of peripatetic sniping activity, but they seem to have disregarded his admission that he was not a member of the Irish Volunteers at the time, even though the 1934 Military Service Pensions Act stated clearly that it applied only to those who had service in named forces, which included the Irish Volunteers, Irish Citizen Army, Fianna Éireann, the Hibernian Rifles and Cumann na mBan. In O'Malley's case pensionable service was awarded to him for a period during which, by his own admission, he did not meet the eligibility criterion of being a member of one of the recognised militias. This is one of a small number of examples where the assessors awarded pensions for service without requiring strict evidence of actual 
membership, so long as the applicant was considered to have been attached to the forces in some way. Ellen Bushell was awarded a pension for 1916 service without having been a member of an actual organisation and the extent of Lily Mernin's intelligence work outside of Cumann na mBan during the War of Independence also earned her a pension. ${ }^{48}$

The generosity of the board in O'Malley's case probably stemmed from his reputation as one of the most notable republican leaders outside Dublin during the War of Independence and Civil War, but possibly also from political interference on his behalf, having lobbied Eamon de Valera to help him secure the pension in 1935: "I told him [de Valera] I really needed the pensions fixed up as I owed money in the USA and needed some to go on with to get back my health. He said he would see [Frank] Aiken about it. It may take a month he said or more". ${ }^{49}$ The nature of O'Malley's service after 1916 would have entitled him to a significant pension in any event and the 1916 service accounted for only $15 / 7$ of the total pension years of 10 19/56 that he was awarded at the highest grade, A, which amounted to a total gross annual pension of $£ 258$ in $1935 .^{50}$ In addition to this he was in receipt of $£ 120$ annually in the form of a disability pension awarded under the 1932 Army Pensions Act in respect of injuries resulting from gunshot wounds received during his capture by the National Army in $1922 .{ }^{51}$ Aiken, the Fianna Fáil Minister for Defence, assisted O’Malley in expediting the award of his pensions, personally sending him the form for the service pension and admitting "We are all very anxious for you and I would be glad to know if you intend coming home. If you were here there would be no difficulty in getting the Military Service pension fixed up within a week or two." Yet, even Aiken could not see any 1916 service in his record: “As far as I can judge you are entitled to a pension from 1917 to 1924. ."52

In contrast to O'Malley, applicants from outside Dublin needed to satisfy the board that they were members of the specified forces on or before 23 April 1916 and carried out all 
orders issued to them during that week, in order to obtain a pension. If not operational they were required to produce evidence to show that this was as a direct result of "orders to the contrary" and to indicate that it had been their "intention and desire to be on active service." 53 A significant number of the pensions for service outside Dublin were only awarded at a late stage in the application process and after lengthy appeals and in some cases legal action. The assessors were initially reluctant to allow any Easter week service to men from the LouthMeath theatre but eventually agreed to recognise as pensionable the actions of those who had been "present at shooting at Castlebellingham and who either subsequently proceeded with the Dundalk contingent to Tyrrellstown House or became detached from that contingent or were sent away on specific missions". With the exception of Donal O'Hannigan, who was allowed to claim service for a full week in his capacity as a GHQ officer ${ }^{54}$, none of the men from the Louth-Meath region were credited with service after the Wednesday of Easter week, on the grounds that by this stage "all opportunity of co-operation with the main Volunteer Forces had admittedly passed". This was in spite of arguments that they had been in contact with Thomas Ashe on Friday and had planned to rendez-vous with him on Sunday, plans which were made redundant by the surrender on Saturday. ${ }^{55}$

The tenuous grounds on which the Louth-Meath men were awarded pensions stood in marked contrast to the high standard set for Galway and Wexford, where the Rising lasted longer and was more intense. In Galway pensions were initially restricted to approximately 220 of "those who took part in the engagements which occurred during the week apart from a few conspicuous leaders in the movement." The majority of these were given to men who could prove that they had participated in attacks on Clarenbridge and Oranmore RIC barracks and engagements with the RIC at Carnmore Cross, in which Constable Whelan was fatally wounded, and Athenry agricultural station (the farmyard). All of these had to prove that they 
had fired shots. More than 80 more who mobilised but did not take part in these actions were refused pensions, in stark contrast to the treatment of the Dublin city volunteers, not all of whom had not engaged in actual fighting. ${ }^{56}$ The vast majority of these refusals were made during 1941 and 1942 when Judge Thomas O'Donnell ${ }^{57}$ was the Referee. The only exception to the rule of awarding pensions solely to those who had fired shots in Galway was the pension awarded to Henry Feeney. Feeney, a Catholic priest who had joined the local Volunteers in late 1915, was in charge of munitions and acted as a chaplain during Easter week. There is no evidence in his pension application that he fired shots and it would appear that as a Catholic priest he was given a dispensation from this expectation by the pension assessors. ${ }^{58}$

In 1944 William Corcoran was refused a pension on the grounds that he had not fired any shots in the engagement at Carnmore cross. While he was part of the Volunteer force that was involved in the engagement, he was located on the Athenry side of the crossroads and as a result outside of firing range. ${ }^{59}$ The Referee at the time, Tadhg Mac Firbisigh [Timothy Forbes], felt compelled to follow the precedent established by his predecessors and the Advisory Committee in the 1930s that the firing of shots constituted a definition of active service in Galway during the Rising, although he had "grave doubts as to the correctness"60 of the definition, and was uncomfortable with the effect it had on discriminating against Volunteers outside of Dublin:

the inequality of treatment meted out to Galway and Wexford and some of the Louth applicants is indefensible, and ... the plea of impossibility to satisfy the claims of all Easter Week Volunteers does not lessen the duty of maximum generosity to men from areas where active service has, in fact, been recognised under both Acts. ${ }^{61}$ 
Corcoran sued the Referee and while three judges of the High Court ruled unanimously against him, they stated their disagreement with the Referee's interpretation of the term "active service" and his belief that he was bound by previous procedure. ${ }^{62}$ This was technically a victory for the Referee but the opinion of the judges was the opportunity MacFirbisigh needed to redress the inequitable treatment of the non-Dublin Volunteers. Following the ruling he decided to recognise the Easter Week service, on a similar basis to that of the Louth men, of Corcoran and seven other Galway Volunteers - Peter Howley, Michael Hanniffy, Thomas B. Cleary, John Daly, John Forde, Martin McEvoy and Patrick Kelly.

His Advisory Committee was not unanimously supportive of the decision. Seamus Robinson endorsed the move, but John McCoy, who had been involved in drawing up the initial criterion that required evidence of having fired shots, argued that the definition had been the result of detailed deliberations by the then Referee [Joseph O'Connor] and Advisory Committee and had been acceptable to the senior Galway officers of the time. Michael Cremen, the Secretary to the Advisory Committee, conceded that the previous standard of "having to fire shots" had been unfair but felt that the Referee's move failed to address other applicants who had been refused and had in some cases better grounds than the Galway men. ${ }^{63}$ It is important to note that the opinion of the High Court with regard to the standard of having fired shots relates solely to the assessment of pension applications in Galway for 1916 service and did affect the assessment criteria for pensions generally after 1945 .

The relaxation of assessment standards, 1943-1958 
The Corcoran decision marked a significant relaxation of the restrictive nature of assessing service that had been applied, not just regarding 1916 service, by both the Board of Assessors and the Referee and Advisory Committee until the mid-1940s. The influence of the two men who held the post of Referee for most of the period from 1943 until the Advisory Committee ceased to function in 1958, MacFirbisigh and Eugene Sheehy, was crucial to this. The office of Referee alternated between both MacFirbisigh and Sheehy for most of the period from 1943 to 1958. MacFirbisigh held it on two occasions, between August 1944 and December 1949, and between October 1951 and September 1954. In the interregnum between his two stints Sheehy served from May 1950 until December 1951 and was the last holder of the office between December 1954 and its cessation in 1958. Art O’Connor served briefly between December 1949 and May 1950 but does not appear to have had much influence on the process during this short period. Diarmuid Fawsitt held the office for a year (1943-4) between O'Donnell and Sheehy and some cases that he adjudicated on suggest that he was less stringent than his predecessors, as in the case of Joseph Robinson which is discussed below.

The High Court had freed MacFirbisigh from the constraint of following the precedents established by his predecessors as Referee, while Sheehy adopted an extremely broad interpretation of the term "active service" that was considerably more generous than any of his predecessors. Sheehy was influenced by legal opinion in a variety of cases relating to soldiers wills that had been delivered in both the Irish and English courts and which gave much broader definitions of what constituted military service. Soldiers in military service were exempt from the normal requirements to have their wills attested to, and case law that upheld the validity of unattested wills drawn up while the soldier was in service provided Sheehy with greater guidance than the nebulous wording of the military service pensions acts. 
He was most strongly influenced by the judgement of Lord Justice Denning in a case in the British Court of Appeal in 1948, upholding the unattested will of an airman. Denning considered the state of "actual military service" to extend beyond those in combat to include:

[those] who serve in the Forces, doctors, nurses, chaplains, Women's Royal Naval Service, Auxiliary Transport Service, and so forth. It includes them all, whether they are in the field or in barracks, in billets or sleeping at home. It includes them although they may be captured by the enemy or interned by neutrals. It includes them, not only in time of war but also when war is imminent. After hostilities are ended, it may still include them, as, e.g., when they garrison the countries which we occupy, or when they are engaged in military operations overseas. In all these cases they are plainly "in actual military service". ${ }^{64}$

Sheehy felt that Denning's definition had particular applicability to Easter week as it did not discriminate "between the front line men (the actual combatant) and those operating away from the smoke and fury of the battle, so long as they are all helping actively to overcome and enemy". He felt that active service "should receive a liberal interpretation" and based his judgement in each individual case on Denning's "very useful analysis". 65

Sheehy was trying to find an appropriate balance between the parsimony of previous Referees and the danger of exposing the pension system to public ridicule through perceptions of excessive generosity. He objected to a proposal to extend pensionable service to "A person who, at any time during Easter Week, 1916, rendered service" in a range of duties that encompassed direct military engagement, guard duty, manufacture and transport of munitions, training, and providing food, laundry and first aid. He felt that this would lead to award of pensions to any members of the relevant forces "who, during Easter Week, gave a Volunteer a cup of tea anywhere, or carried a message anywhere, or cut a telegraph wire anywhere, or 
blocked a road anywhere", and did not wish to see "Easter Week service ... cheapened in this way."66

Sheehy's unwillingness to discriminate against those who had mobilised but had not been to the forefront of combat in 1916 might have been influenced by his own military involvement in the Rising. As a commissioned officer in the $4^{\text {th }}$ Battalion of the Royal Dublin Fusiliers, he was sent to defend Dublin from the rebels, although he saw little actual combat: "I myself carried no arms - not even a revolver - and the only weapon in my possession was the regimental walking stick". ${ }^{67} \mathrm{He}$ went on to serve in France at the Somme and Ypres and subsequently as an intelligence officer. ${ }^{6}$ Sheehy also had close political connections to the republican movement. Although a home ruler who answered Redmond's call to enlist in 1914, and the son of the Irish Parliamentary Party MP, David Sheehy, he also had impressive Fenian ancestry. His father had been in the Fenians in his youth, and his uncle, Fr Eugene Sheehy, was a prominent supporter of radical nationalist causes, who blessed rebels in the GPO during the Rising. ${ }^{69}$

More crucially, his sister, Hanna Sheehy-Skeffington, was one of the highest profile women in the republican movement, whose husband, Francis, was controversially killed during the Rising. While Eugene Sheehy did not share the political views of either his uncle or his sister, he certainly had intimate knowledge of the revolutionary movement and the impact which it had on those who participated in it. The more lenient approach of the later Referees reflected a general sense that pension applications had not always been assessed fairly in the past. The government recognised this in 1949 introducing new legislation allowing applicants who had been rejected previously to re-apply and in effect permited new applications from those who had not applied previously. ${ }^{70}$ 
The variable interpretations of different Referees applied at different times underlines the subjective nature of decisions to recognise service and the extent to which timing could affect significantly the applicant's chance of success. A significant proportion of the men who were eventually recognised as having participated in the Rising did not receive their recognition until the 1950s, as a result of the new legislation and the generosity of the later Referees. Over one-quarter of the Galway male pensioners (100 of 379, or 26 per cent) were awarded their pensions because of the more liberal interpretations applied by MacFirbisigh and Sheehy. In addition to the eight men awarded pensions on foot of the Corcoran decision, MacFirbisigh awarded 56 pensions and Eugene Sheehy 31 to men who petitioned under the 1949 act. Five fresh Galway applications were successful in the 1950s, four under MacFirbisigh and one under Sheehy. The more favourable atmosphere clearly encouraged some of these new applications. In 1955 Sheehy allowed one and a half days of 1916 service to James Cleary, a member of Fianna Éireann in Athenry, who was only fourteen at the time of the Rising and whose principal activities in Easter week were delivering communications and providing supplies for the Volunteers. Cleary had never previously applied for a pension and it is highly unlikely that an application prior to 1949 would have been successful given the non-combat nature of his service and his age. ${ }^{71}$

In Wexford 113 men were initially awarded pensions from a list of 270 supplied by a local Old IRA Brigade Committee as having mobilised during that week. This included two categories: men who had been in the Irish Volunteers prior to Easter week and whose preparatory work had facilitated the extent of the Rising in Enniscorthy, and those who were mobilised and armed and used their arms during Easter week itself. The final figure of successful applicants rose to 238. Sixty-nine of these (29 per cent) had to wait until the 1950 s 
for their service to be recognised, with Sheehy responsible for allowing the majority (47), while MacFirbisigh granted 22.

MacFirbisigh and Sheehy were also responsible for awarding a significant portion of the service allowed to women in both of these theatres; no women were recognised for service in Louth and Meath. In general, women experienced greater difficulty in having pensionable service recognised. ${ }^{72}$ Gertrude (Colley) Murphy struggled to get service recognised for the Friday of Easter week, because she had left her post in the GPO, even though this had been on the orders of Patrick Pearse. ${ }^{73}$ Of the 22 Galway women who received pensions, seven (32 percent) were awarded by MacFirbisigh and Sheehy, who awarded six and one respectively, between 1947 and 1954. Six of these were after the passing of the 1949 act. Between 1951 and 1955 Sheehy awarded pensions to four (12.5 per cent) of the thirty-two Wexford women who received pensionable service for their activities in $1916 . .^{74}$

\section{Recognising active service outside the designated theatres}

There were a few notable deviations from the geographic principle of restricting pensions to the four designated areas. Thirty men and two women were recognised as having 1916 service for actions elsewhere. Three of these were men who died as a result of the Rising and whose families received dependants' pensions; the most notable was Roger Casement, whose sister, Agnes Newman, was awarded a pension in 1926. Similar awards were made to the families of Daniel Sheehan and Cornelius Keating, who drowned at Ballykissane Pier, near Kilorglin, on Good Friday while trying to meet Casement. ${ }^{75}$ 
While service in Kerry linked to Casement's operation was not among the four areas designated by the Board of Assessors, in practice they awarded some service for it. In December 1924 Seán Ó Murthuile was awarded full service for Easter week, even though his service was rendered in Limerick, while en route to collect the arms from Casement's abortive landing. His was the highest award possible under the 1924 act - full service equating to 14 years pensionable service that entitled him to an annual pension of $£ 350$. As he was no longer a serving army officer, having been forced to resign during the army mutiny, he was able to draw down the pension immediately. ${ }^{76}$

His was one of nine military service pensions awarded in which the Board of Assessors deviated from its regulation on restricting service geographically. In 1925 John Peter McGuire from Laois was awarded a pension recognising 1/5 service for the period from 1 April 1916 to 31 March 1917, making it difficult to isolate the extent to which this was a recognition of his service in Easter week per se, though it appears to be for his role in disrupting the railway line at Colt Wood on the eve of the Rising. ${ }^{77}$ A second pension awarded that year to James Wall was likely to have been granted because of his arrest and as in the case of Ó Murthuile, was for actions linked to the Casement operation. ${ }^{78}$

With the exception of these three awards the Board of Assessors adhered to its restrictions on recognition of 1916 service until 1927 when, under pressure from dissatisfied and influential supporters of the government in the Dáil and the army, it relaxed the restriction somewhat. In October 1925, Alastair McCabe, a former Cumann na nGaedheal TD and senior army officer during the Civil War, who had been one of the most prominent volunteers in Sligo prior to the Truce, complained to president W.T. Cosgrave that he had been denied Easter week service, whereas "A number of people who did much less that I did Easter Week have been given the benefit of [this] period in their pension." ${ }^{, 79}$ The board 
subsequently re-opened his case, awarding 2/5 service for the period from 1 April 1916 to 31 March 1917, effectively increasing his annual pension by $£ 30 .{ }^{80}$ There is no evidence that this was as a result of intervention from Cosgrave but it is not the only case in which a petition to the president subsequently resulted in the board overturning an unfavourable decision. ${ }^{81}$ Andrew Lavin, a sitting Cumann na nGaedheal TD at the time he was refused 1916 service in 1925, also had his case revised on identical lines to McCabe at the same time in early $1927 .{ }^{82}$

The impact of timing on a successful outcome can be seen in the applications of the army's Quarter-Master General, Michael Brennan, and his brother, Patrick, which were not assessed by the board until later in 1927. Michael Brennan, one of the most prominent volunteers in Munster during the War of Independence and one of the highest profile IRA leaders there to take the pro-Treaty side, was awarded service for the entire period that included Easter week, in spite of the limited nature of his actions in Clare and Limerick and his failed attempts to link up with Liam Mellows in Galway. He was unable to draw down his pension until he left the army in 1940. Paddy Brennan was also given recognition for the entire period. In both cases their imprisonment during 1916 was probably a factor, although as the cases of Lavin and McCabe indicate, the board was more flexible in its interpretation of eligible regions for 1916 service by this stage. ${ }^{83}$

Favourable timing might also explain the award in January 1927 of Easter week service to James Ruane, whose sole action of consequence appears to have been the theft of rifles from the National Volunteers in Balla, County Mayo, armaments which were subsequently returned. ${ }^{84}$ Micháel Ó Muircheartaigh was the final pensioner recognised for service by the Board of Assessors outside the main theatres. His award was also made in 1927 but as it was for service in Kerry, the rationale appears to have been the board's unofficial recognition of Kerry as a fifth region of operations. ${ }^{85}$ 
The Referee and Advisory Committee appointed under the 1934 act applied the original 1916 geographical limitations even more stringently than their predecessors had done. Between 1934 and 1949 only nine more pensions were awarded for service not directly linked to those four main theatres. The exceptions mirrored some of those awarded by their predecessors on the Board of Assessors: Tom McEllistrim and Robert Monteith, were involved in Casement's landing; Eamon Fleming had been in Dublin before being dispatched to Laois on orders from the Volunteer Executive; and Joseph O'Kelly was arrested while on active duty in Roscommon. ${ }^{86}$

The Referee's strict interpretation of continuity of active service following periods of imprisonment $^{87}$ was the subject of legal challenges from Joseph Robinson and Francis O'Brennan for their claims to service during the Rising. Robinson, who was the older brother of the Advisory Committee member, Seamus Robinson, was arrested in Glasgow on 20 January 1916 when procuring arms for the planned Rising, and remained in prison throughout that year until his release on Christmas Eve. He was initially denied pensionable service for Easter week by Joseph O'Connor in $1935^{88}$ on the technical grounds that as the legislation did not recognise service in the forces prior to 1 April 1916, he could not be deemed to be in service at the date of his arrest, which in turn meant that his imprisonment did not count as a break of continuous service. This decision was challenged by his legal counsel, Seán MacBride, and supported strongly by an impressive bi-partisan array of veterans, including Ernest Blythe, Bulmer Hobson, Michael Staines, Joseph O’Doherty, Barney Mellows and Eamon de Valera, all of whom agreed that his imprisonment was due to his activities in preparing for the Rising and with Blythe's view that "without the shadow of a doubt ... the only reason why he was not actually in the Rising was that he was interned in Scotland". 
O’Connor's decision was upheld by Thomas O’Donnell in April 1943, but eventually overturned by a new Referee, Diarmuid Fawsitt, in the following year. While the reasons for Fawsitt's decision are not recorded he might not have considered himself to be as bound by O'Connor's precedents as O’Donnell did. Robinson had also produced written support from legislators who were central to the formulation of both the 1924 and 1934 acts (Blythe and De Valera) to the effect that the legislation never envisaged excluding cases such as his, and legal opinion from Seán MacBride and Cecil Lavery arguing against the logic of the original Referees' decisions. ${ }^{89}$ Seamus Reader, who was also arrested in the same operation as Robinson and imprisoned between January and December 1916, was treated similarly. Joseph O’Connor denied him any service in 1937 but Tadhg MacFirbisigh awarded him full service for Easter week in 1944, presumably on the basis that his case was identical to that of Robinson, although Reader was also able to produce new evidence. ${ }^{90}$

The opinion of the Attorney General in the case of Eamon Martin was also a possible factor in the Robinson decision. Martin was initially refused the highest pension rank (A) - to which he claimed membership of the Irish Volunteer Executive between 1913 and 1915 entitled him - also on the grounds of non-recognition of service in the forces prior to 1 April 1916. The legislation awarded Grade A pensions to those who were members of that executive "at any time prior to the $11^{\text {th }}$ day of July 1921 ", but Thomas O'Donnell only believed this to "apply to any time from $1^{\text {st }}$ April, 1916 to 11 July, 1921". The Attorney General cast sufficient doubt on this interpretation for Martin's claim to be conceded: "it is not impossible to suggest that the membership of the Volunteer Executive at any time from its constitution until 11 July, 1921, was regarded as worthy of being recognised by a higher rate of pension." ${ }^{91}$ Robinson referred to this decision in his appeal. The decision in Robinson's case also appears to have influenced Fawsitt's decision to award service for the 
entire period of Easter week to Francis O'Brennan, who was in prison throughout it having been arrested after an armed altercation with the RIC in Tullamore, County Offaly [King's County] in March 1916. ${ }^{92}$

The last two exceptional 1916 awards were made to James Riordan (Kerry) and Michael O'Callaghan (Tipperary), the success of whose applications was no doubt based on clear evidence that they had fired shots at policemen. O'Callaghan's engagement was particularly significant, resulting in the fatalities of two RIC men, Sergeant Thomas Rourke and Constable John Hurley, and his application was supported by Dan Breen who praised him for having "saved the name of Tipp[erary] by his actions during that famous week". 93 Establishing that one had fired shots was the criterion used by the Referee and Advisory Committee during this period for service in Galway, a test that Riordan and O'Callaghan clearly passed.

Of the two women awarded 1916 service outside of Dublin, Nora Thornton was recognised in 1941 for four days of activity in the unofficial fifth theatre of Kerry. ${ }^{94}$ Timing was central to Kathleen Keyes' McDonnell's application. 1949 was significant in her case, but not because of the passage of the new pension act; "it was only on the enactment of the Republic of Ireland Act that her husband and herself felt they could make these applications." In 1951 Sheehy awarded her three days' service for Easter week in Cork. The nature of her service is not very clear in her pension file, but her statement to the Bureau of Military History, given previously in 1947, indicated that she had assisted Terence MacSwiney and Tomás MacCurtain in their efforts to mobilise Volunteers in Cork. ${ }^{95}$

Sheehy and MacFirbisigh's leniency also extended to awarding service for action outside the principal theatres. A further nine men had such service recognised by them; seven by Sheehy and two by MacFirbisigh for activities in Laois, Kilkenny, Tipperary and 
Waterford.$^{96}$ In the case of Patrick Muldowney from Laois, Sheehy awarded him service on the basis of evidence that he had "helped to cut railway line between Portlaoighise and Abbeyleix". ${ }^{97}$ In many cases the service awarded was minimal, but recognition, especially in their own localities and in comparison to former comrades, was probably as important as the small financial benefit, as can be seen in the case of Patrick Ramsbottom who complained that his award did not match that of Patrick Muldowney, of whom he was a superior officer; "apart from the monetary compensation", Ramsbotton considered the inferior award to constitute "a serious reflection on his record and character". 98

The discrepancy in the award of the 1916 medal to four of the men involved in disrupting the railway line Laois, but to refuse it to four others who were involved in the same incident underlines the vicissitudes of pension eligibility. Muldowney, Ramsbottom, Colum Holohan and Michael Sheridan are all recognised 1916 veterans because their overall pension applications did not succeed until after the 1949 legislation was introduced. Prior to 1949 Lar and Thomas Brady, John Muldowney and Michael Gray had been awarded pensions for service between 1917 and 1921, but their claims for 1916 recognition had been rejected. As the 1949 legislation allowed unsuccessful applicants to re-apply but did not permit successful applicants who had been refused recognition for a certain period of service to appeal the unsuccessful aspect, the former group re-applied successfully achieving 1916 recognition but the latter four had no recourse to challenge the original decision, even though the Department of Defence conceded many years later that there was a "prima facie" case that they were "equally deserving of the award". ${ }^{99}$ Commandant Michael Gray's descendants sought for many years to have the medal awarded posthumously, and while there was evident sympathy among civil servants and politicians, the limitations of the relevant statutes did not allow for this. ${ }^{100}$ 


\section{Conclusion}

The special recognition given to descendants' of 1916 veterans by the Irish state during the Rising centenary commemorations reflects the significance that being a recognised veteran of the Easter Rising still holds in Irish society. ${ }^{101}$ For the veterans themselves securing that acknowledgement in their own lifetime carried symbolic and financial significance. Being recognised by the state as a veteran of 1916 was an important distinction for those upon whom it was conferred. Some of the state's actions indicate that 1916 veterans occupied a higher status within the overall hierarchy of revolutionary veterans. They were the first group to be awarded service medals, for the twenty-fifth anniversary in 1941. As veterans aged and concern for their welfare arose, 1916 veterans were the first recipients in 1943 of a meanstested special allowance for those "incapable of self-support by reason of age or permanent infirmity"; it was later extended to all veterans. ${ }^{102}$

The MSPC list of veterans with recognised 1916 service helps us to calculate more accurately many people were "out" in Easter week. This list of over 2,500, taken together with the 1916 roll of honour and the work of historians on local garrisons in Dublin, Louth and elsewhere, would suggest that between 3,000 and 4,000 people were involved in some way in rebel activity at some stage during Easter week, and approximately one-tenth were women. Yet it is far from being a definitive calculation of the numbers who were "out" in 1916, and does not claim to be such. Inclusion in the list for deceased veterans was often dependant on the subsequent actions of their families, so that Harry Boland and Michael Collins are there but Constance Markievicz and Cathal Brugha are not.

Exclusion does not mean these men and women did not play a role in the Rising. The decision to limit service to Dublin city and county, Galway, Wexford, Meath and Louth 
placed official restrictions on who was to be recognised as such by the state. This was seen as particularly unfair by the Ulster rebels and only a few whose claims were difficult to deny, who applied at the right time, or had useful political connections, were able to establish their service outside of these limitations.

The timing of an application could affect its success. Under the 1924 act, applications or appeals made after 1927 were treated more leniently. 1949 was the turning point for many eventually successful applications. The combination of new legislation and more sympathetic Referees, resulted in a significant proportion receiving pensions during the 1950s on the basis of service that would not have been entertained by the assessors during the 1930s or early 1940s. Some of those who had received pensions during the 1940s for War of Independence or Civil War service, but not for the Rising, were denied the opportunity to re-open their claims for 1916 service. It is reasonable to assume that some would also have received recognised 1916 veteran status if they had been allowed to do so.

Even within the designated theatres geography was a crucial factor in success. Dublinbased volunteers had a much easier time establishing their credentials. The ease with which Ernie O'Malley's application for a pension was approved on his own account of sniping activities during the latter half of Easter week, while unattached to any of the recognised forces, stands in marked contrast to the experience of William Corocran, who was a member of the Irish Volunteers from 1914 and mobilised for all of Easter week. ${ }^{103}$ O'Malley's case also shows how political connections helped in some cases; his appeal to de Valera and Frank Aiken probably helped to expedite his application and possibly to result in a successful outcome. Alastair McCabe and Andrew Lavin exploited their links to Cumann na nGaedheal for increased pensions and senior army officers like the Brennan brothers were awarded full Easter week service outside the designated theatres. ${ }^{104}$ 
An understanding of the context in which decisions to award or reject pensions, and the significance of such variables as the Referees' attitudes, the timing of an application, or political influence, need to be appreciated if scholars are to utilise the information contained in the MSPC accurately and effectively. Michael Gray's 1916 activities in Laois were on a par with those of Patrick Ramsbottom but the timing of the latter's application, the impact of the 1949 act and the divergent attitudes of Referees led to one having recognised 1916 service and the other not.

Investment in archives will be one of the enduring legacies of the Irish state's official actions to commemorate the decade of its establishment. The full potential of the MSPC has yet to be revealed and it will likely expand considerably the understanding of the War of Independence and Civil War period, as it has for the Rising in terms of helping to ascertain the extent of involvement, the attitude to revolutionary veterans in independent Ireland, and the significance of official recognition of having done one's part to free Ireland. 


\section{Bibliography}

Bateson, Ray. The Rising Dead: RIC \& DMP. Dublin: Irish Graves Publications, 2012.

Coleman, Marie. "Military Service Pensions and the Recognition and Reintegration of Guerrilla Fighters after the Irish Revolution.” Historical Research (forthcoming, 2018).

Coleman, Marie. "Cumann na mBan in the War of Independence." In Atlas of the Irish Revolution, edited by John Crowley et al, 400-408. Cork: Cork University Press, 2017.

Coleman, Marie. “Compensating Irish Female Revolutionaries, 1916-1923.” Women’s History Review 27 (2017): 915-934.

Coleman, Marie. “Service Medals and Special Allowances.” In Department of Defence, The Military Service (1916-1923) Pensions Collection. The Medals Series. Dublin: Department of Defence, 2016.

Coleman, Marie. "Military Service Pensions for Veterans of the Irish Revolution, 1916-23." War in History 20 (2013): 201-21.

Connell, Joseph E. A. Jnr. Who's Who in the Dublin Rising 1916. Dublin: Wordwell, 2015.

Department of Defence. The Military Service (1916-1923) Pensions Collection. The Medals Series Dublin: Department of Defence, 2016.

Department of Defence. Guide to the Military Service (1916-1923) Pensions Collection, edited by Caitriona Crowe. Dublin: Department of Defence, 2012.

Doyle, Tom. "Drownings at Ballykissane: A Tragedy that altered the course of the 1916 Rising." In Kerry 1916: Histories and Legacies of the Easter Rising. A Centenary Record, edited by Bridget McAuliffe et al, 113-119. Kerry: Irish Historical Publications, 2016. 
English, Richard and Cormac K.H. O’Malley (eds), Prisoners: The Civil War Letters of Ernie O’Malley. Dublin: Poolbeg, 1991.

English, Richard. Ernie O’Malley: IRA Intellectual. Oxford: Oxford University Press, 1995.

Ferriter, Diarmaid. A Nation and not a Rabble: The Irish Revolution, 1913-1923. London: Profile, 2015.

Hart, Peter. Mick: The Real Michael Collins. London: Macmillan, 2005.

Irish Times Ltd. Sinn Fein Rebellion Handbook, Easter 1916. Dublin: Irish Times, 1917. Joye, Labhras and Brenda Malone. "The Roll of Honour 1916." History Ireland 14 (2006): $10-11$.

McAvinue, Brendan. "Policing in County Louth.” In County Louth and the Irish Revolution, 1912-1923, edited by Donal Hall and Martin Maguire, 86-108. Kildare: Irish Academic Press, 2017.

McCann, Lorraine. "Compiling the names of the County Louth Volunteers who mobilised, Easter Week 1916.” In County Louth and the Irish Revolution, 1912-1923, edited by Donal Hall and Martin Maguire, 281-298. Kildare: Irish Academic Press, 2017.

McCarthy, Mark. Ireland's 1916 Rising: Explorations of History-making, Commemoration and Heritage in Modern Times. Surrey: Ashgate, 2012.

McGarry, Fearghal. The Rising, Ireland, Easter 1916. Oxford: Oxford University Press, 2010.

McGuire, James and James Quinn (eds), A Dictionary of Irish Biography from the Earliest Times to 2002. Cambridge: Cambridge University Press/Royal Irish Academy, 2009.

Morrison, Eve. "Witnessing the Republic: The Ernie O'Malley notebook interviews and the Bureau of Military History compared.” In Modern Ireland and revolution: Ernie O’Malley in context, edited by Cormac K.H. O’Malley, 124-40. Dublin: Irish Academic Press, 2016. 
Morrison, Eve. "Class, gender \& occupation among the Bureau of Military History witnesses \& Ernie O’Malley interviewees who were 'out' in 1916.” Saothar, 41 (2016): 59-67.

Nic Dhábhéid, Caoimhe. "Fighting their Fathers' Fight: The Post-revolutionary Generation in Independent Ireland.” In Uncertain Futures: Essays About the Irish Past for Roy Foster, edited by Senia Pašeta, 148-160 Oxford: Oxford University Press, 2016.

O’Malley, Cormac K.H. and Nicholas Allen (eds), Broken Landscapes: Selected Letters of Ernie O’Malley, 1924-1957. Dublin: Lilliput, 2011.

O’Malley, Ernie. On Another Man’s Wound. Dublin: Anvil Books, 1979.

O’Malley, Ernie. Army Without Banners. London: Four Square, 1967.

O’Malley, Ernie. On Another Man’s Wound. London: Rich \& Cowan, 1936.

Sheehy, Eugene. May it Please the Court. Dublin: C.J. Fallon, 1951.

Townshend, Charles. Easter 1916: The Irish Rebellion. London: Penguin, 2005.

Wills, Clair. Dublin, 1916: The siege of the GPO. London: Profile, 2009.

Wren, Jimmy. The Four Courts Garrison and Mendicity Institution Easter Week 1916: A Biographical Dictionary. Dublin: Dublin City Council, 2016.

Wren, Jimmy. The GPO Garrison Easter Week 1916: A Biographical Dictionary. Dublin: Geography Publications, 2015. 
Table 1: 1916 veterans with recognised active service

\begin{tabular}{|l|r|r|r|r|}
\hline & Military Service Pensions & Medals & Dependants' pensions & Dept. of Defence List \\
\hline Male & 2,075 & 112 & 171 & 15 \\
\hline Female & 206 & 15 & $\mathrm{n} / \mathrm{a}$ & $\mathrm{n} / \mathrm{a}$ \\
\hline Total & 2,281 & 127 & 171 & 15 \\
\hline Percentage & $88 \%$ & $5 \%$ & $6.5 \%$ & $0.5 \%$ \\
\hline
\end{tabular}

Table 2: Geographical distribution of 1916 military service pensions

\begin{tabular}{|l|r|r|}
\hline & Number & $\%$ \\
\hline Dublin & 1,544 & $68 \%$ \\
\hline Galway & 401 & $17 \%$ \\
\hline Wexford & 268 & $12 \%$ \\
\hline Louth/Meath & 39 & $2 \%$ \\
\hline Other & 29 & $1 \%$ \\
\hline Total & 2,281 & $100 \%$ \\
\hline
\end{tabular}

${ }^{1}$ Dáil Éireann Debates, vol. 34, 3 April 1930, 542.

${ }^{2}$ Dáil Éireann Debates, vol. 34, 3 April 1930, 541.

${ }^{3}$ Townshend, Easter 1916, 348.

${ }^{4}$ Wills, Dublin, 1916, 144-6.

${ }^{5}$ http://www.militaryarchives.ie/collections/online-collections/military-service-pensions-collection

${ }^{6}$ Irish Times, 26 Apr. 2016; Dáil Éireann Debates, vol. 936, 31 January 2017, written answer no. 389.

${ }^{7}$ See for example Nic Dhábhéid, "Fighting the Fathers' Fight." 
${ }^{8}$ Examples include Gilbert Ryan, who took part in the Rising in Galway, and was a permanent inmate of Ballinasloe psychiatric hospital from 1931 until his death in 1964, (Military Service Pensions Collection [hereafter MSPC] W34E4480: Gilbert Ryan).

${ }^{9}$ The initial release listed 2,577. This was subsequently updated to 2,594 . The list of names is available on the Military Archives website http://www.militaryarchives.ie/fileadmin/user_upload/MSPC/_documents/Veterans_of_Easter_Week _1916_with_recognised_military service-3 June 16.pdf (accessed 8 September 2017).

${ }^{10}$ Irish Times, 27 and 30 June 2015; “The 1916 medal.” In Department of Defence, The Military Service (1916-1923) Pensions Collection. The Medals Series.

${ }^{11}$ Irish Times, Sinn Fein Rebellion Handbook, 69

${ }^{12}$ Joye and Malone, “The Roll of Honour 1916," 10-11.

${ }^{13}$ Connell, Who's Who in the Dublin Rising 1916, 2; for a comparison between the Roll of Honour and the MSPC see Morrison, "Class, gender \& occupation", p. 60.

${ }^{14}$ Wren, The GPO Garrison Easter Week 1916, v-vi.

${ }^{15}$ Wren, The Four Courts Garrison and Mendicity Institution.

${ }^{16}$ Connell, Who's Who in the Dublin Rising 1916, 2.

${ }^{17}$ Morrison, "Class, gender \& occupation”, p. 60.

${ }^{18}$ Townshend, Easter 1916, 229; Ferriter, A Nation and not a Rabble, 157; McCarthy, Ireland's 1916 Rising, 64.

${ }^{19}$ McCann, "Compiling the names of the County Louth Volunteers who mobilised, Easter Week 1916," 286-91.

${ }^{20}$ Coleman, "Military Service Pensions for veterans of the Irish revolution," 201-21.

${ }^{21}$ For a more detailed account of the assessment process see Coleman, "Military Service Pensions and the Recognition and Reintegration of Guerrilla Fighters after the Irish revolution".

22 (MSPC MD909: Harry Boland).

${ }^{23}$ (MSPC 1D178: James Connolly; 1D478: Roger Casement [Agnes Newman]).

${ }^{24}$ These statistics are based on a revised version of the initial list produced in 2016. As the release of the MSPC is on-going additions may be made if new files relating to previously undiscovered 1916 veterans are uncovered, but these are unlikely to result in any major changes to the overall numbers and percentages discussed here.

${ }^{25}$ This presumably refers to the destruction of Johnny Collins's family home in April 1921, see Hart, Mick, 20-21.

${ }^{26}$ (MSPC WDP23755: Michael Collins). 
${ }^{27}$ I am grateful to Comdt. Patrick Brennan, former director of the MSPC Project, for this personal insight based on family knowledge.

${ }^{28}$ (MSPC MD912: Michael Collins).

${ }^{29}$ Gearóid O’Sullivan, “Military Service Pensions Act, 1924,” 16 October 1924, (MSPC SPG/6).

30 "Easter Week, 1916. Historical", Appendix to Report of Referee, T. MacFirbhisigh, 11 December 1945, (National Archives of Ireland [hereafter NAI] DT S13602A).

${ }^{31}$ (MSPC MSP34REF56175: Patrick McCartan).

${ }^{32}$ (MSPC 24SP308: Sean Cusack).

${ }^{33}$ (MSPC 2D499: John McElvogue).

${ }^{34}$ (MSPC MSP24803: James Hannan).

${ }^{35}$ The figures are based on the location of the veterans' service during the Rising, as stated in the pension, and not on the address given in the database of names released. These addresses usually refer to an applicant's address at the time the pension was awarded, as opposed to during 1916; for example, Donal O'Hannigan has a Dublin address in the database list but his service was in County Louth. The figure for Meath and Louth excludes Dublin Volunteers who also took part in action at Ashbourne who are included in the Dublin statistics.

${ }^{36}$ McGarry, The Rising, 210-11.

${ }^{37}$ McAvinue, "Policing in County Louth," 92-3.

${ }^{38}$ Bateson, The Rising Dead, 95.

${ }^{39}$ McGarry, The Rising, 233-4; Townshend, Easter 1916, 228-31.

${ }^{40}$ McGarry, The Rising, 240-43.

41 “Easter Week, 1916," n/d, (NAI DT 13602A).

${ }^{42}$ English, Ernie O’Malley, 5.

${ }^{43}$ Service certificate, 11 July 1935, (MSPC W34A6: Ernest Bernard O’Malley).

${ }^{44}$ O’Malley, On Another Man’s Wound (London, 1936 edition), 47-8.

${ }^{45}$ Ernie O’Malley to Mrs [Molly] Childers, 26 November-1 December 1923. In Prisoners, edited by English and O’Malley, 73.

${ }^{46}$ On Another Man's Wound was subsequently republished in Ireland by Anvil Books in 1979, 1990 and 2002 and contains this revised version of his Easter week experience, as does the version published in the United States in the 1960s, Army Without Banners, see O'Malley, On Another Man's Wound (Dublin: Anvil Books, 1979 edition), 38-41 and Army Without Banners (London: Four Square, 1967 edition). 
${ }^{47}$ Ernie O’Malley to Markham, 14 May 1934. In Broken Landscapes, edited by O'Malley and Allen, 3.

${ }^{48}$ (MSPC MSP34REF22326: Ellen Sarah Bushell); Coleman, "Cumann na mBan in the War of Independence," 400.

${ }^{49}$ Ernie O'Malley to John Raleigh, 4 June 1935. In Broken Landscapes, edited by O'Malley and Allen, 122. Frank Aiken was the Fianna Fáil Minister for Defence at the time.

${ }^{50}$ (MSPC W34A6: Ernest Bernard O’Malley).

${ }^{51}$ (MSPC WV268: Ernest Bernard O’Malley).

${ }^{52}$ Frank Aiken to Ernie O’Malley, 4 Feb. 1935, (Ernie O’Malley Papers, Tamiment Library, New York University, AIA 060, Box 3, Folder 20). I am grateful to Dr Eve Morrison for providing this reference. For an assessment of the impact of the pension of O'Malley's finances and later life see Morrison, "Witnessing the Republic".

${ }^{53}$ Gearóid O’Sullivan “Active Service during week commencing 23 ${ }^{\text {rd }}$ April, 1916,” (MSPC SPG/6).

${ }^{54}$ O'Hannigan's full service was only conceded following a length appeal and with the benefit of intervention from Seán MacEntee, the Minister for Local Government and Public Health, (MSPC MSP34REF16541: Donal O’Hannigan).

55 "Easter Week, 1916. Historical," appendix to report of Referee, T. MacFirbhisigh, 11 December 1945, (NAI DT S13602A).

${ }^{56}$ Ibid.

${ }^{57}$ Thomas O'Donnell was a former Irish Parliamentary Party MP and leader of the short-lived Irish National League party in the 1920s, before joining Fianna Fáil in the 1930s, see J. Anthony Gaughan, “O’Donnell, Thomas (Tom) (1871-1943)." In Dictionary of Irish Biography [hereafter DIB] edited by McGuire and Quinn.

${ }^{58}$ (MSPC MSP34REF18030, W34D997: Henry Joseph Feeney).

${ }^{59}$ (MSPC MSP34REF9368: William Corcoran).

${ }^{60}$ Tadhg MacFirbisigh, memorandum, 21 October 1946, (MSPC MSP34REF9368: William Corcoran).

${ }^{61}$ Report of Referee, T. MacFirbhisigh, 11 December 1945, (NAI DT S13602A).

${ }^{62}$ Ireland, High Court of Justice, The State (William Corcoran) v. The Referee, Military Service Pensions Act, 1934 (MSPC 1934/LEG/11).

${ }^{63}$ (MSPC MSP34REF9368: William Corcoran).

${ }^{64}$ Re. Wingham (Deceased), Andrews and Another v. Wingham, 2AER, 908. 
${ }^{65}$ Eugene Sheehy, "Military Service Pensions Acts (1934-1949). Memorandum from Referee to Advisory Committee," (University College Dublin Archives, Seán MacEoin Papers, P151/526).

${ }^{66}$ Eugene Sheehy to Minister for Defence [Seán MacEoin], 13 Dec. 1956 (MSPC DOD/3/13070 (Pt. I)); see also, Patrick Brennan, “'Active Service': Changing definitions”. In Guide to the Military Service (1916-1923) Pensions Collection, edited by Crowe, 71-2.

${ }^{67}$ Sheehy, May it please the court, 90-91.

${ }^{68}$ Daire Hogan, “Sheehy, Eugene (1883-1958).” In DIB, edited by McGuire and Quinn.

${ }^{69}$ Owen McGee, "Sheehy, David (1844-1932)" and "Sheehy, [Fr] Eugene (1841-1917)." In DIB, edited by McGuire and Quinn.

${ }^{70}$ Military Service Pension (Amendment) Act (1949) www.irishstatutebook.ie

${ }^{71}$ (MSPC MSP34REF64045: James Cleary).

${ }^{72}$ Coleman, "Compensating Irish Female Revolutionaries, 1916-1923."

${ }^{73}$ (MSPC W34REF46870: Annie (Barrett) Allum; W34REF14667: Dolly (Broderick) Fleming; W34REF14668: Margaret Rose Grealy; W34REF59605: Mary (Rooney) McNamara; W34REF3257: Kathleen (Cleary) Kennedy; W34REF14582: Katie (Fahy) Nelly; W34REF28883: Brigid Lardner).

${ }^{74}$ (MSPC W34REF55133: Lily Ennis; W34REF58418: Kate Murphy; W34E9094: Elizabeth O’Brien; W34REF24575: Christina Ward).

${ }^{75}$ (MSPC W1D475: Roger Casement, W1D418: Cornelius Keating, W1D484: Daniel Sheehan); Doyle, "Drownings at Ballykissane," 114-19.

${ }^{76}$ (MSPC W24SP1 and W24E1 Seán Ó Murthuile [John Hurley]); Patrick Long, “Ó Murthuile, Seán (1881-1941).” In DIB, edited by McGuire and Quinn.

77 (MSPC W24SB197: John Peter McGuire).

${ }^{78}$ (MSPC W24B372: James Wall).

${ }^{79}$ (MSPC, W24SP869: Alasdair McCabe).

${ }^{80}$ (MSPC, W24C29: Alasdair McCabe).

${ }^{81}$ See also the case of Brigid Lyons, (MSPC W24SP1361: Brigid Lyons); Coleman, "Compensating Irish Female Revolutionaries."

${ }^{82}$ (MSPC W24SP4060: Andrew Lavin).

${ }^{83}$ (MSPC W24E22: Michael Brennan and W24SP2483: Patrick Brennan); for details of their actions during Easter week, see Bureau of Military History [hereafter BMH] WS1068: Michael Brennan www.bureauofmilitaryhistory.ie.

${ }^{84}$ (MSPC W24SP11502: James Ruane; BMH WS1588: Seán T. Ruane). 
${ }^{85}$ (MSPC W24SP1349: Michéal Ó Muircheartaigh).

${ }^{86}$ (MSPC MSP34REF840: Tom McEllistrim; MSP34REF56789: Robert Monteith; W34D1805 and MSP34REF56091: Joseph Edward O’Kelly).

${ }^{87}$ Breaks in active service were accounted for if occasioned by "arrest, imprisonment, internment or deportation" but the applicants had to show that they had been in service prior to their arrest and that this service was continued on release, Military Service Pensions Act (1934), section 2

www.irishstatutebook.ie

${ }^{88}$ Seamus Robinson was not yet a member of the Advisory Committee at this stage.

${ }^{89}$ (MSPC MSP34REF298: Joseph Robinson).

${ }^{90}$ (MSPC MSP34REF4300 and W34C197: Seamus Reader).

${ }^{91}$ (MSPC MSP34REF47556: Eamon Martin).

92 (MSPC MSP34REF59902: Francis O’Brennan).

${ }^{93}$ (MSPC, MSP34REF54971: James Riordan; W34E7977 and MSP34REF4189: Michael O'Callaghan).

${ }^{94}$ (MSPC MSP34REF1015 and 34E5120: Nora Thornton.

95 (MSPC 34D2430 and MSP34REF61207: Kathleen Keyes McDonnell; BMS WS88: Mrs Kathleen McDonnell).

${ }^{96}$ James Browne, Cornelius Deere, Colum Holohan, Michael Kearney, Patrick Muldowney, Eamon Ó Duibhir, Patrick O’Mahony, Patrick Ramsbottom and Michael Sheridan.

${ }^{97}$ (MSPC MSP34REF47014: Patrick Muldowney).

${ }^{98}$ John F. Murtagh to Secretary, Military Service Pensions Branch, 31 October 1953, (MSPC 34B65: Patrick Joseph Ramsbottom).

${ }^{99}$ Memorandum, "Qualification for the 1916 medal", c. 1984 (MSPC 24C316: Michael Gray). My thanks to Cécile Gordon, Senior Archivist of the MSPC for drawing my attention to the significance of this case and for wider observations on this article.

${ }^{100}$ See various correspondence with government ministers, 1984-1990 (MSPC 24C316: Michael Gray).

101 3,500 descendants of those who fought in the Rising attended a special event with the President of Ireland on Easter weekend 2016 and were also given privileged viewing points for the main commemorative parade on Easter Sunday, Irish Times, 26 March 2016.

${ }^{102}$ Coleman, "Service Medals and Special Allowances."

${ }^{103}$ (MSPC MSP34REF52142: William Corcoran).

104 (MSPC 24SP9375: Michael Brennan; 24SP2483: Patrick Brennan). 